\title{
ASPECTOS, DESDOBRAMENTOS E POSSIBILIDADES ACERCA DA NOÇÃO DE GEWALT NO PENSAMENTO DE WALTER BENJAMIN
}

\author{
Lucas Carvalho Lima Teixeira
}

\begin{abstract}
RESUMO
Buscar-se-á compreender, nos primeiros tópicos do presente trabalho, de que modo a crítica histórica benjaminiana atua no âmbito da discussão acerca da autoridade e dos fundamentos da autoridade do poder soberano e, portanto, do direito, tematizando, para tanto, a noção de Gewalt como seu motor histórico; no último tópico, tratar-se-á da discussão acerca do messianismo e da noção benjaminiana de revolução, em vistas da possibilidade de dissolução do aparato dominante da autoridade.
\end{abstract}

Palavras-Chave: Benjamin; poder-violência (Gewalt); autoridade; direito.

\section{ASPECTS, UNFOLDINGS AND POSSIBILITIES ON THE NOTION OF GEWALT IN THE THOUGHT OF WALTER BENJAMIN}

\begin{abstract}
The aim of this work consists in to understand how the benjaminian historical critique acts in the scope of the discussion about the authority and the foundations of the authority of the sovereign power and, therefore, of the Law, thus thematizing the notion of Gewalt as its historical engine; in the last topic, it will be discussed the Messianism and the Benjaminian notion of revolution in view of the possibility of dissolution of the dominant apparatus of authority.
\end{abstract}

Keywords: Benjamin; power-violence (Gewalt); authority; Law. 


\section{Introdução: a "lei dos meios"}

Benjamin propõe, em seu ensaio Crítica da Violência : Crítica do Poder (Zur Kritik der Gewalt), de 1921, esquadrinhar o fenômeno do direito na modernidade. O que estaria guardado na essência do Estado de Direito, isto é, como ele atua historicamente? Através de qual elemento a sua presença histórica poderia ser satisfatoriamente definida? Para responder a esses questionamentos, o autor voltará sua atenção para o significado do termo Gewalt - que, na língua alemã, se desdobra simultaneamente nos sentidos do poder e da violência - como lei específica do modo pelo qual o direito funda e mantém sua existência histórica enquanto tal. A crítica benjaminiana ao direito é uma crítica histórica direcionada para o elemento limítrofe de diferenciação dessa estrutura de autoridade; se se fala, aqui, de uma "essência" do Estado (e do direito), não se visa a proposição de uma ontologia - ao menos não em seu sentido clássico metafísico - mas, antes, coloca-se em jogo o questionamento de um fenômeno histórico-político; no mais, se se utiliza indistintamente ora as noções de Estado e direito, ora as noções de autoridade e soberania ou poder, isso se deve à indistinção intrínseca ao próprio problema, como se buscará demonstrar. Dada a significativa identidade entre os conceitos de poder e violência, representada pelo termo alemão Gewalt, como seria possível elaborar uma crítica ao direito tendo em vista a delimitação do meio (modus) específico através do qual se essencializa a sua existência histórica? Sobretudo, quais seriam as repercussões decisivas que emanariam das nervuras da "lei dos meios" do direito? A questão nodal apela antes pela identificação certeira deste modo - ou meio - via do qual o direito se essencializa historicamente:

\footnotetext{
Embora se possa dizer, com razão, que a economia atual, considerada como um todo, se compara muito menos a uma máquina que para, quando o foguista a abandona, do que a uma fera que endoidece, quando o domador Ihe dá as costas - o caráter violento de uma ação não deve ser julgado segundo seus efeitos ou fins, mas apenas segundo a lei de seus meios (BENJAMIN, 1986, 170).
}

Se a categoria essencializadora do Estado é aquilo que se convencionou chamar de monopólio do poder, conceito responsável por configurar a noção própria da soberania tradicional, enquanto instância centralizadora e apropriativa da potência de ação sobre a esfera das relações humanas e da palavra final incumbida de normalizar os conflitos do mundo contingente, para onde indicam exatamente os 
aspectos contidos nesse conceito histórico-político? Qual seria o significado da mútua implicação entre os vocábulos "monopólio" e "poder" na obra de Walter Benjamin? O vocábulo poder é representado, na língua alemã, pelo termo Gewalt; Gewalt, contudo, circunscreve os sentidos de poder e a violência em uma só e mesma natureza histórico-política. Destarte, torna-se possível afirmar que Gewalt significa, radicalmente, algo como o poder enquanto violência e a violência enquanto poder, intrincadamente identitários entre si enquanto caracterizadores do Estado (de) Direito. ${ }^{1}$ Por conseguinte, o conceito de monopólio do poder se apresenta, de modo imediato, como um monopólio da violência, ou seja, a potência absoluta e concentrada de alterar, interferir e controlar o espectro dos fenômenos humanos. No plano da vida humana, esta violência investe especificamente sobre as relações éticas, ou seja, sobre a vida mesma dos homens no âmbito político; portanto,

A tarefa de uma crítica da violência* pode ser definida como a apresentação de suas relações com o direito e a justiça. Pois, qualquer que seja o efeito de uma determinada causa, ela só se transforma em violência, no sentido forte da palavra, quando interfere em relações éticas" (BENJAMIN, 1986, 160). ${ }^{2}$

Ora, no interior do circuito entre a Gewalt jurídica, a justiça e a vida dos homens, duas tradições político-jurídicas se ergueram e disputaram o locus da legitimação do monopólio da violência por parte do direito. Ambas inseridas na esteira de uma concepção finalista da ação, e, portanto debruçadas sobre a relevância de princípio e os desdobramentos oriundos da relação entre meios e fins, temos, de um lado, a tradição do direito natural, representante por excelência da primazia da justiça dos fins enquanto legitimadora dos meios disponíveis para concretizá-los, e, do outro lado, a tradição do direito positivo, ancorada na perspectiva lógico-racional do processo enquanto intervalo de mediação legitimador dos fins jurídicos. Acerca da querela montada sob a discussão atinente à topografia dos meios e fins entre o direito natural e o direito positivo, Benjamin conclui que:

\footnotetext{
${ }^{1}$ Contrabandeamos o artifício dos parênteses de Sartre, especificamente de O Ser e o Nada. Lá, o autor os utiliza a fim de driblar o mau entendimento que as regras da gramática poderiam ocasionar. Deste modo, os parênteses indicam o grau de simultaneidade inexorável entre os termos do vocábulo; destarte, quer-se com isso significar: Estado é Direito, Direito é Estado.

$2 \mathrm{O}$ asterisco sobre o vocábulo violência é um artifício gráfico elaborado pelo tradutor a fim de delimitar o sentido específico do termo a partir de sua correspondência com o alemão Gewalt. Doravante, as aparições do asterisco em citações sobre o vocábulo poder e violência concernem, ambos, ao sentido de Gewalt, o poder-violência típico do Estado (de) Direito e do espectro de autoridade que confere seu significado histórico e, "paradoxalmente", mítico.
}

Mestrando no PPG em Filosofia da Universidade Federal de São Paulo. Brasileiro; residente em Campinas-SP. e-mail: led.Iclt@gmail.com 


\begin{abstract}
À tese, defendida pelo direito natural, do poder ${ }^{*}$ como dado da natureza, se opõe diametralmente a concepção do direito positivo, que considera o poder* como algo que se criou historicamente. Se o direito natural pode avaliar qualquer direito existente apenas pela crítica de seus fins, o direito positivo pode avaliar qualquer direito que surja apenas pela crítica de seus meios. Se a justiça é o critério dos fins, a legitimidade é o critério dos meios. No entanto, não obstante essa contradição, ambas as escolas estão de acordo num dogma básico comum: fins justos podem ser obtidos por meios justos, meios justos podem ser empregados para fins justos. O direito natural visa, pela justiça dos fins, "legitimar" os meios, o direito positivo visa "garantir" a justiça dos fins pela legitimidade dos meios (BENJAMIN, 1986, 161).
\end{abstract}

Não cabe no escopo da presente reflexão pontuar as delicadas diferenças contidas em cada uma dessas tradições. Aqui, a diferença entre o direito natural e o direito positivo redunda simplesmente no fato de que, para este, a resolução da justiça se dá a partir do critério de validação dos fins jurídicos através da retidão processual dos meios empregados para atingi-lo, enquanto para o primeiro são os fins eles mesmos e em razão deles mesmos, como qualificações naturais do que é inerente à vida dos homens, que dizem a justiça dos meios para preservá-los. No primeiro, é a justiça intrínseca aos fins que determina a justiça dos meios; no segundo, é a justiça dos meios que determina a justiça dos fins. Não obstante, "ambas as perspectivas ficam presas à ideia segundo a qual existe uma adequação entre meios e fins, já que meios justos devem gerar fins justos estes são obtidos por aqueles" (SELIGMANNSILVA, 2005, p. 26). Assim, a Gewalt seria legitimada, na tradição do direito natural e na tradição do direito positivo, através do pressuposto de justiça ora dos fins, ora dos meios, porém sem jamais interrogar a legitimidade não-metafísica do poder-violência do qual se valem para executar os fins a que se propuseram. É por este motivo que Benjamin julga as concepções tradicionais acerca dos meios, elaboradas por estas duas teorias político-jurídicas, insuficientes para uma adequada e rigorosa análise crítica, uma que compreenda os meios do Estado (de) Direito desde o ponto de vista de sua história e não dos pressupostos metafísicos articulados para estabelecê-lo. Ademais, será a própria coadunação metafísica entre meios e fins que a crítica do direito colocará em questão ao realocá-la em sua história, ao empurrá-la de volta à sua gênese perdida onde o que se encontra, no limite, é a verdade da sua "préhistória" imanente, palco anarkhós de toda legitimação mítica natural ou racional.

Com efeito, se esgotássemos a tentativa de esquadrinhar a efetiva "lei dos meios" do direito no modelo do direito natural ou no modelo do direito positivo, certamente decairíamos no raciocínio hermético para o qual nos conduzem as duas 
teorias: "a violência dos meios é legítima porque os fins que ela visa são justos, e estes por sua vez são justos porque encarnam a justiça mesma, o que torna os meios para atingi-los justos em igual medida" ou, por sua vez, "os fins que se preveem na positivação serão justos na medida em que os meios para atingi-los forem legítimos, e a legitimidade dos meios é legítima porque encarna a legitimidade mesma, o que torna os fins, atingidos pelo reto trâmite, justos em igual medida". Ora, mas qual é o fundamento histórico e não-metafísico da legitimidade do poder-violência dos meios jurídicos empenhados para consolidar seus fins? A investigação sobre essa pergunta exige uma análise acerca da concretude histórica da práxis soberana, desatrelada do espectro dos seus fins e interrogada segundo o meio mesmo que é necessário durar, independentemente do conteúdo dos fins e da legitimação que se lhe interponha, para que sua própria existência seja conservada. Em termos espinosanos, o que caracterizaria o conatus do Estado (de) Direito ${ }^{3}$ Ao que, de saída, adverte Benjamin:

Ficaria em aberto a pergunta, se a violência em si, como princípio, é moral, mesmo como meio para fins justos. Para decidir a questão, é preciso ter um critério mais exato, uma distinção na esfera dos próprios meios, sem levar em consideração os fins a que servem (BENJAMIN, 1986, 160).

Assim, a crítica da sua história deslocará os olhos precisamente para o instante fundacional de qualquer legitimação, lá onde a Gewalt jurídica não se encontra com nada mais além de si mesma. O pensador alemão nos convida, então, a questionar a ambivalência de fundo presente no movimento entre a guerra e a paz, donde irrompe a fundação do direito:

\footnotetext{
${ }^{3}$ Nas proposições VI e VII da Terceira Parte de sua Ética, Da Origem e Natureza dos Afetos, Espinosa nos oferece a sua definição de conatus, isto é, o esforço imanente de cada coisa, no modo próprio como cada coisa é, para persistir no seu ser; respectivamente: "Cada coisa, o quanto está em suas forças, esforça-se para perseverar em seu ser" e "O esforço pelo qual cada coisa se esforça para perseverar em seu ser não é nada além da essência atual da própria coisa" (2015, p. 250-251). Ao valermo-nos da noção de conatus, queremos indicar precisamente isto: a Gewalt, a violência fundadora do direito e lei (modus) própria da sua existência histórica, não é franqueada de sua proveniência anômica na medida em que se transforma em "instituição" mas, ao contrário, e enquanto sua essência e origem, persiste enquanto esta violência sob a forma da sua manutenção, independentemente do projeto "justificador" que se lhe interponha - em suma, enquanto existe, o direito existe necessariamente neste seu modo. Ressalte-se, porém, que não há no ensaio de Benjamin - Crítica da Violência: Crítica do Poder - menção expressa ao conceito de conatus tal como Espinosa o pensou, tampouco apontamentos acerca deste conceito aplicado à crítica do direito proposta inicialmente pelo pensador alemão. Não obstante, o exercício hermenêutico elaborado sobre o significado histórico da Gewalt, como constituição do sentido moderno da soberania, nos leva a considerar o peso elementar que Espinosa possa ter exercido na vida intelectual de Walter Benjamin, além, é claro, de este haver citado de maneira assertiva o Tratado Teológico-Político logo nos primeiros parágrafos do ensaio em questão: Cf. BENJAMIN, 1986, 160-161. Considerando, ainda, a remissão positiva que consta em $A$ Vida dos Estudantes, Benjamin demonstra haver frequentado com assiduidade a filosofia de Espinosa.

Mestrando no PPG em Filosofia da Universidade Federal de São Paulo. Brasileiro; residente em
}

Campinas-SP. e-mail: led.Iclt@gmail.com 
De fato, a palavra "paz" - numa acepção em que ela se torna correlato da palavra "guerra" - designa, por assim dizer, a priori uma sanção de toda vitória, sanção necessária e independente de todas as demais relações jurídicas. (Existe ainda uma outra acepção de "paz", não metafórica e política, a de Kant, quando fala da "paz perpétua".) A sanção consiste em reconhecer a nova situação como um novo "direito", independentemente se ela necessita de fato alguma garantia para ter continuidade ou não (BENJAMIN, 1986, 164).

Ora, se o decreto da paz não passa de uma sanção ao novo direito, imposta pelos vitoriosos a fim de legitimar aquilo que eles mesmos construíram sobre os cadáveres dos derrotados, qual tipo de legitimidade antecederia o meio violento via do qual este direito é fundado? Não haveria como afirmar a antecedência do próprio direito, natural ou positivo, pois é apenas a promessa da sua fundação que está em jogo na guerra; na guerra originária mesma, onde o que há é o completo vazio de direito, jaz somente a violência investida na fundação, contudo sem qualquer fundamento que represente ou suporte sua legitimidade. Destarte, a verdade acerca da "pré-história" do direito deslinda-se enquanto verdade histórica dos seus meios: a violência da sua fundação, no seio da guerra, consiste numa violência radicalmente soberana e, por definição, ilimitada. O nascimento do Estado (de) Direito não acontece, portanto, através da paz, do contrato ou da razão, mas através de uma violência sem nómos, inexoravelmente impregnada em seu gene, e constitutiva da delimitação essencial do seu modo histórico de existir. ${ }^{4}$ Em outros termos, a violência precede, no âmbito da criação do direito, toda e qualquer legitimidade. No limite, a violência aparece como a própria essência do Estado (de) Direito. A violência (Gewalt) enquanto "lei dos meios" do direito não implica, por conseguinte, apenas em artefato histórico da sua fundação, mas, imediata e paralelamente, na contínua lei a-nômica da sua própria manutenção. É em razão dessa genealogia da violência jurídica que

\footnotetext{
${ }^{4}$ Essa força jurídica sem direito foi extensamente refletida por um dos mais importantes comentadores e, por assim dizer, herdeiros hodiernos de Walter Benjamin, a saber, o pensador italiano Giorgio Agamben. A crítica de Agamben à soberania moderna, compreendida pela tese de que seria, de fato, o próprio estado de exceção a constituir o centro da sua estrutura na relação de cunho teísta com a vida nua, é tributária direta e explícita das reflexões de Benjamin em seu ensaio Crítica da Violência: Crítica do Poder (Zur Kritik der Gewalt), bem como de Carl Schmitt e o embate subterrâneo travado com Benjamin pela letra de sua Teologia Política (Politische Theologie). Especificamente sobre esta precedência a-nômica da violência fundadora do direito, aduz Agamben: "A tentativa do poder estatal de anexar-se à anomia por meio do estado de exceção é desmascarada por Benjamin por aquilo que ela é: uma fictio iuris por excelência que pretende manter o direito em sua própria suspensão como força de tei" (AGAMBEN, 2004, 92). A força de tei agambeniana delimita, de maneira muito refinada, aquilo que Benjamin pretendia demonstrar com a análise da violência focada estritamente na lei histórica dos seus meios, e não em sua relação com fins legitimadores pospostos.
}

Mestrando no PPG em Filosofia da Universidade Federal de São Paulo. Brasileiro; residente em Campinas-SP. e-mail: led.Iclt@gmail.com 
Benjamin pousará sobre esta sua dupla função, pois, "Se a primeira função da violência passa a ser a instituição do direito, sua segunda função pode ser chamada de manutenção do direito" (BENJAMIN, 1986, p. 165). Deste modo, cada movimento para os fins comporta já a rematerialização da violência fundacional a-nômica e instituidora de legitimidade; assim como a violência jurídica precede e impregna a legitimidade jurídica, o espírito da guerra também precede e impregna o decreto - ou, mais rigorosamente, no gerúndio: o decretando violento - da paz. Em suma,

\begin{abstract}
Segundo o autor, é exatamente esta violência de guerra que deve servir de modelo para compreendermos qualquer violência. Da recente guerra europeia, ele deduz que o militarismo revela uma dupla face da violência: enquanto uma compulsão (Zwang) para seu uso generalizado como meio para fins de Estado, ou seja, como meio para fins jurídicos, ela se revela como "instituidora de direito" e, por outro lado, como "mantenedora de direito". Deste modo Benjamin atinge o cerne da questão da Gewalt enquanto composição indissociável de violência e poder (jurídico). Sua crítica da Gewalt visa estas suas duas faces. Mesma a máxima bem-intencionada de Kant, "aja de tal modo que você use a humanidade, tanto em nome da tua pessoa como na de qualquer outro, sempre como fim, nunca apenas como meio...", é vista como insuficiente e ingênua para se fazer uma crítica da Gewalt (SELIGMANN-SILVA, 2005, 27).
\end{abstract}

O início, o meio e o fim do Estado tornam-se, por conseguinte, uma só e a mesma coisa: a conservação, via violência, do poder de se valer da violência para atingir fins delimitáveis ao infinito, violência que, no início de tudo, decidiu sobre a instalação do seu primado. Nada há no corpo do Estado (de) Direito exceto a compulsão (Zwang), como assim a chamou Benjamin, à conservação da sua essência, isto é, a conservação unívoca do sintagma soberano poder-violência. Aqui, no âmbito deste giro eterno do direito em torno de si mesmo, entramos num território onde o poder jurídico é, de fato, poder mítico. Estamos na esfera do mito.

\title{
1 Gewalt, mito e mímesis
}

A mais poderosa insígnia do caráter mítico da Gewalt jurídica reside no fato de que o único fim que ela pode garantir, dada a crítica da história de sua essência, consubstancia-se na garantia do meio específico para fazer cumprir qualquer tipo de fim. O único elemento eterno que resta no direito é a violência modular intrínseca à sua dupla função instituidora e mantenedora; aos fins, embora sempre existam, sobra somente a marca da transitoriedade e da contingência. Destarte, 
[...] talvez deva se levar em consideração a surpreendente possibilidade de que o interesse do direito em monopolizar o poder diante do indivíduo não se explica pela intenção de garantir os fins jurídicos, mas de garantir o próprio direito. Possibilidade de que o poder, quando não está nas mãos do respectivo direito, o ameaça, não pelos fins que possa almejar, mas pela sua própria existência fora da alçada do direito (BENJAMIN, 1986, 162).

O monopólio da violência não existe, portanto, para assegurar determinados fins jurídicos, contudo para assegurar o próprio monopólio do poder-violência. A Gewalt existe em função da própria Gewalt. Não obstante, e exatamente em decorrência deste giro eterno em torno de si, visto que a essência do direito é o seu próprio meio, qual lhe seria o único elemento ameaçador? A resposta está vinculada a certo efeito de espelhamento repulsivo: da mesma maneira como o Dorian Gray, de Wilde, manifesta abjeção quase insuportável ao horror do retrato, que nada mais revela do que a abjeção que nutre pelo que ele mesmo é, mas fora de si, ao direito também se coloca neste espelhamento repulsivo; a única coisa que ameaça sua existência é a presença, iminente ou em andamento, de um novo direito, a Gewalt, que ele mesmo é, pulsando fora de si.

Em outros termos, o direito, em sua acepção crítica enquanto poder-violência atuante no seio da dupla função instituidora e mantenedora, tem como seu principal algoz o espectro de um novo direito sendo fundado, ou seja, que a função mantenedora não repita a memória da sua vitória mas, fatalmente, da sua derrota. A ameaça do novo direito representa, no limite, o alvorecer instituidor de uma nova Gewalt, tão enviscada no comprometimento com o poder a-nômico que ela mesma exerce e no empuxo inevitável à concentração ilimitada deste poder quanto aquela do direito cuja ruína se anuncia. Do embate entre esses dois conati soberanos, só um poderá, de fato, perseverar em seu ser. É nesta senda que Benjamin evoca a greve e o bandido enquanto extratos ameaçadores ao direito instituído em manutenção:

Através de que função a violência* parece, com toda a razão, tão ameaçadora para o direito, tão temida por ele? Isso se mostra justamente nos casos em que, mesmo segundo a ordem judiciária atual, o emprego da violência* ainda é admitido. Em primeiro lugar, trata-se do caso da luta de classes na forma do direito garantido de greve dos operários (BENJAMIN, 1986, 163).

No esquema materialista dialético, a luta de classes aparece como instante histórico-político da consciência de classe e, prontamente, como reconhecimento objetivo dos obstáculos estruturais que uma determinada organização social e econômica - no contexto em questão, o regime capitalista - impõe contra os interesses da classe operária. Compreendendo-se, no interior desta estrutura, 
segundo a categoria marxiana da força de trabalho - matriz concreta da produção -, o operariado projeta na greve, isto é, na paralisação geral de um setor da produção a partir da sua base, um dos seus mecanismos de abastecimento do movimento críticodialético que escancara as contradições latentes da estrutura atual de relações materiais. Com efeito, a greve se apresentaria ao direito instituído como um ameaçador concentrado de potência instituidora do novo direito, pois o que ela opera quando paralisa e postula, ou seja, quando transcende aquilo mesmo que já se encontra em regime de manutenção pelo poder atual, consiste precisamente na experiência estética de Dorian Gray: vê-se a si mesmo, mas fora de si; por conseguinte, se o direito é a sua própria Gewalt, aquilo que vê na greve, a ponto de tornar-se para ele tão abjeta, repulsiva e ameaçadora, é o devastador expediente de outridade (Alienos) da Gewalt. Impossível conter, com o esquadrinhar deste expediente, a indicação acerca do que parece ser o pano de fundo basilar da relação travada entre o direito atual e o seu outro, a saber, a investida metafísica responsável pela constituição do subjectum e a sua inerente cisão radical com o mundo, o que nada mais anuncia do que a promessa da dominação sobre ele.

Enquanto monopólio do poder-violência em sua dupla função instituidora e mantenedora, o direito posiciona-se imediatamente como o mais potente, absoluto e indivisível subjectum no centro daquilo que passará a ser a ordem do seu cósmos. Nesta ordem, nada escapa à tonalidade essencial da sua Gewalt, pois nenhuma outra violência fundadora é tolerada se o prospecto da sua subjetividade-soberana é cumprido. Em suma, a Gewalt jurídico-soberana revolve-se precisamente num espaço onde somente ela dispõe do poder para arrastar o mundo conforme o vetor de sua manutenção, onde somente ela arroga-se para si o ser do fundamento sobre todas as relações éticas, ou seja, o cósmos específico do direito. Sem embargo, e se levarmos a sério a intuição benjaminiana acerca do conatus histórico persistente no direito, acarreta em conclusão inevitável que o aparecimento do outro subjectum, isto é, o eu mesmo, mas fora de mim, não apenas ameaça o direito atual com o fardo prospectivo dos derrotados mas que, sobretudo, perturba cada fibra da sua essência soberana e, portanto, da sua identidade mesma. Aqui, a presença do novo direito, o outro do direito atual, deflagra para este o prenúncio da sua morte. Nenhum outro subjectum da mesma natureza pode durar, pois o conatus mesmo da Gewalt jurídica consiste, radicalmente, em um ser total. Eis a fórmula escatológica daquilo que se arrasta como 
um espectro possessivo por toda a tradição ocidental, em âmbito ético ou epistemológico, político, religioso ou moral: a autoridade. Com esta, todavia, nos defrontaremos mais adiante.

Ora, a greve exibe a amostragem potente da outridade do conatus jurídico, a Gewalt outra. Como, então, o direito atual poderia vencer a investida dessa ameaça à sua essência soberana? A resposta, Benjamin já nos concedeu: o mecanismo de manutenção do direito atual, pego de encontro com a ameaça de um novo direito, conclui-se no assim chamado "direito de greve". A estratégia de poder aqui presente perfaz-se no movimento de absorção da violência outra sob o território da violência atual; conceder o direito de greve não significa, deste modo, padecer simplesmente frente à força imediata ou possível de uma nova fundação do direito mas, no revés dessa conclusão apressada, significa enquadrá-la sob a soberania da sua própria potência, concentrá-la, adequando-a, enquanto fortificação do seu próprio conatus. Em suma, o direito de greve afigura-se como uma estratégia sub-reptícia - mas não menos sistemática - de controle dos reflexos potentes e outros (Alienos) da Gewalt soberana atual. Uma vez inserida nos quadros do direito, a greve tem a aura de sua violência fundacional fatalmente drenada. Aqui, o que se apresentava inicialmente como possibilidade de subversão do direito que vigora - ainda que, no mais das vezes, para repetir o ciclo da instituição e da manutenção - é reconvertido em alimento para este último. Com efeito, a mesma estratégia é operada em todos aspectos da vida e das relações humanas: capturar o que encarna a ameaça e aumentar sua própria potência enquanto autoridade concentrada; ademais, demolir o que resiste à captura. Assim, no caso da greve, bem como no de qualquer outro conteúdo de direito,

O Estado pode muito bem argumentar que um exercício de greve em todas
as empresas é contra a lei, uma vez que a greve não tenha tido em cada
empresa o motivo específico, pressuposto pelo legislador. Essa diferença de
interpretação expressa a contradição objetiva de uma situação de direito,
segundo a qual o Estado reconhece um poder*, a cujos fins, enquanto fins
naturais, às vezes é indiferente, na hora H (no caso da greve geral
revolucionária), porém, é hostil (BENJAMIN, 1986, 163).

É o circuito entre a dupla função instituidora e mantenedora do direito que está colocado no centro do seu conatus soberano. Se a concentração absoluta do poderviolência inscreve-se enquanto fator de distinção desta sua essência e, por conseguinte, aponta para um espaço de ação do direito que é totalizante, engolindo sob o seu apetite de dominação insaciável qualquer lampejo de potência que não seja 
a sua mesma, então algo um tanto mais elementar e proporcionalmente catastrófico entoa da marcha avassaladora do direito, lá onde a promessa do passo à frente é, por antecipação, hipostasiada naquele que o precede, e assim ao infinito. Este algo mais elementar, dizíamos, é o colapso do tempo. Colocamo-nos, aqui, face a face com um tópico decisivo da crítica benjaminiana ao poder, pois o colapso do tempo diz respeito à elipse fundamental da Gewalt enquanto subjectum soberano, violência permanentemente faminta que se nutre da violência outra, enquanto meio essencial legitimador de si mesmo, enquanto instância única e última de poder sobre a vida, enquanto manutenção infinda do instante a-nômico instituidor de todo nómos, por fim, enquanto manutenção violenta da violência que ela mesma é. Totalização ostensiva e presumida da lei dos seus próprios meios; indeterminação em relação a si e determinação absoluta de todo o resto; recordação implacável e permanente do seu instante originário: são todos elementos que se agremiam para enrijecer a musculatura atemporal do poder do Estado. O direito em sua essência não é algo que passa. O direito não comporta finitude. E, portanto, o colapso do tempo o desvela precisamente como mito. Em outros termos, o poder mítico da Gewalt jurídica se manifesta na forma do destino (Shicksal). Cautelosa e pacientemente - no que por vezes parece transitar entre admoestação, alerta e pessimismo ${ }^{5}$ em relação ao pano de fundo intelectual e político da primeira metade do século $X X-$, Benjamin nos convoca a pensar as ressonâncias decisivas deste esquema mítico-destinal do direito, sobretudo em vistas daquilo que se propõe a ser, de fato, uma crítica. Em colisão deliberada com o imperativo de Kant - "aja de maneira que você use a humanidade sempre como um fim, nunca apenas como um meio" -, Benjamin afirma:

\begin{abstract}
Se, por um lado, não se deve poupar críticas a essa ordem, que o direito pretende conservar com razão, por outro lado, qualquer interpelação dessa ordem é impotente, quando se apresenta apenas em nome de uma "liberdade" sem rosto e incapaz de apontar uma ordem de liberdade superior. Sua impotência é total, quando não questiona o próprio corpo da ordem jurídica, mas apenas leis ou costumes jurídicos isolados, que então serão protegidos pelo direito com o seu poder, que consiste na alegação de que só existe um único destino e que justamente o status quo e o elemento ameaçador pertencem à sua ordem de maneira irrevogável. Pois o poder* mantenedor do direito é um poder ameaçador (BENJAMIN, 1986, 165).
\end{abstract}

\footnotetext{
${ }^{5}$ Pessimismo aqui entendido como conceito crítico a uma certa filosofia da história, muito peculiar ao pensamento de Benjamin. Coloca-se na contramão do otimismo de algumas esquerdas e socialdemocracias da época e, o que acaba sendo o mesmo, da noção de progresso fomentada pelo historicismo burguês: Cf. LÖWY, 2005, p. 23-24. Sobre o conceito de pessimismo presente na Tese VII de Sobre o Conceito de História: Cf. LÖWY, 2005, p. 75.
}

Mestrando no PPG em Filosofia da Universidade Federal de São Paulo. Brasileiro; residente em Campinas-SP. e-mail: led.Iclt@gmail.com 
O autor distingue, neste excerto, aquilo que tomaremos licença para chamar de dimensão superficial, ou transitória, da dimensão mítica, ou destinal, da ordem jurídica. A primeira é definitivamente inadequada para se pensar a crítica do direito, e isto porque se mantém enredada numa discussão acerca dos conteúdos fragmentados que compõem o ordenamento. Nada parece tão estranho àqueles que se erguem em defesa da dimensão transitória do direito quanto a perspectiva crítica, pois o que esta última detecta consiste pontualmente em colocar no centro do jogo o conatus mesmo do direito, isto é, em encarar a essencialidade da sua essência no âmbito da história. Muito preocupada com os fins, a dimensão transitória prostra-se cega para a lei dos meios, o que a impede de perceber o continuum da Gewalt jurídica rumo ao mito do direito.

A crítica que se desenrola na dimensão mítica, por sua vez, apreende a verve do que está em questão para a essência do conatus jurídico, ou seja, o destino que ele mesmo é para o cósmos sob o seu domínio. Enxergar a dimensão mítica enquanto mito do direito é o salto para trás que a crítica benjaminiana realiza ao interrogá-lo segundo a constituição da lei essencial de sua própria história. Não é a análise sobre leis particulares e uma ordem jurídica fragmentária que proporcionará o acesso à verdade histórica de sua essência. Para o direito, essa essência historicamente constituída é a violência (Gewalt). Destarte, o mito do direito revolve-se no destino em relação ao qual cada um já está de antemão prometido, o destino da Gewalt soberana. É em razão desse caráter destinal do mito jurídico, solapamento do tempo pela Gewalt eternizada, que Benjamin classificará o direito como um poder ameaçador.

Só que sua ameaça não tem o sentido de uma intimidação, como costumam interpretá-lo teóricos liberais desinformados. A intimidação no sentido exato exigiria uma definição contrária à essência da ameaça e não atingida por lei nenhuma, uma vez que existe a esperança de escapar a seu braço. A lei se mostra ameaçadora como o destino, do qual depende se o criminoso lhe sucumbe (BENJAMIN, 1986, 165).

Assim, temos até aqui que o direito é constituído em seu conatus por um poderviolência radicalmente concentrado em torno de si, um conatus subjetivo intransigente com a manifestação de potência de qualquer outro alocado fora do seu domínio e, precisamente por isso, totalizante, a partir de seu próprio poder, tal qual a força do destino. Eis o mito. Sem embargo, qual seria, por assim dizer, o paroxismo do mito jurídico, isto é, onde ele alcança a sua topografia mais elevada? Para Benjamin, isso 
acontece em duas frentes, não necessariamente distintas no que comungam de essencial, contudo distintas no que concerne a certo tipo de intensidade daquilo que manifestam ao agir. A primeira delas é a decisão judicial propriamente dita; a segunda, é a polícia. Mas o que está no epicentro da ação das duas frentes e, por conseguinte, o que se coloca como o objeto de inclinação por excelência do paroxismo jurídico, implica numa só e mesma coisa; o autor a encontrará na discussão de relevância ou seja, nos quadros da dimensão mítica - sobre a pena de morte. Estamos, pois, lidando com o poder, a partir da intensidade decisória e da intensidade policial, sobre a vida e a morte dos homens:

Sentiam os críticos, talvez sem poder explicá-lo e sem querer senti-lo, que uma contestação da pena de morte não ataca uma medida punitiva, nem as leis, mas o próprio direito na sua origem. Pois se a sua origem for a violência*, a violência coroada pelo destino, não está longe a suspeita de que na instituição do poder* supremo - o poder sobre vida e morte, o qual se apresenta na forma da ordem jurídica -, as origens do poder-violência interferem de maneira representativa na ordem existente e ali se manifestam de forma terrível (BENJAMIN, 1986, 166).

A decisão soberana, ou seja, aquela que é atuante em qualquer uma das hipóstases do Estado (de) Direito, quer seja o magistrado, quer seja a polícia, quer seja o presidente ou o ministro, é sempre e de forma imediata uma manifestação da Gewalt jurídica em sua dupla e simultânea função instituidora e mantenedora, sobre a integralidade da vida dos homens, e, deste modo, também uma decisão acerca da morte. O paroxismo do mito do direito se dá, pois, na decisão ela mesma. Ora, mas não foi dito que o poder mantenedor do direito é um ato de repetição permanente do seu instante instituidor? Não foi dito que aquilo que se mantém propriamente no poder mantenedor é a violência soberana constituidora do conatus jurídico e escatologia do subjectum metafísico, aquilo que se caracteriza precisamente pela ânsia potente de engolir qualquer potência outra que a ela resista? Bem, se assim for, então o paroxismo decisório, nos termos em que o deciframos, está instalado no coração do poder mantenedor do direito, o que faz dele, quase de maneira paradoxal, um paroxismo permanente. A violência do direito - soberana, mítica e destinal - é um poder cuja potência atua em estado latente sobre aquilo que Benjamin identificou, logo no início, como o espaço elementar do domínio da Gewalt, a saber, as relações éticas, que nada mais são do que a morada do homem. Com efeito, a decisão sobre a vida e 
a morte jamais cessa no território soberano do direito. A polícia apenas escancara a força dessa repetição a-nômica:

Do primeiro [o poder instituidor do direito] se exige a legitimação pela vitória, do segundo [o poder mantenedor do direito], a restrição de não se proporem novos fins. O poder* da polícia se emancipou dessas duas condições. É um poder* instituinte do direito - cuja função característica não é promulgar leis, mas baixar decretos com expectativa de direito - e um poder* mantenedor do direito, uma vez que se põe à disposição de tais fins. [...] Ao contrário do direito que, na "decisão" fixada no espaço e no tempo, reconhece uma categoria metafísica, graças à qual ele faz jus à crítica, a observação da instituição da polícia não encontra nenhuma essência. Seu poder* é amorfo, como é amorfa sua aparição espectral, inatacável e onipresente na vida dos países civilizados (BENJAMIN, 1986, 166). ${ }^{6}$

É agora o momento de clarificar que aquilo que já sempre se faz presente na ambivalência necessária entre o poder instituidor e o poder mantenedor do direito é, enquanto mito, movimento mimético (mímesis) do direito. Apenas por esta via poderemos compreender como, de fato, toda decisão concerne à retomada do primeiro ato inaugural violento - autolegitimador e indeterminado - do direito atual. Seja baixando seus próprios fins e os operando, como no caso da polícia, seja buscando os fins de um reino metafísico e fazendo-os cumprir-se no mundo imanente, como na concepção "clássica" do magistrado, o que acontece no interior da ordem jurídica é a mímesis da sua própria violência originária, soberana e instauradora. $\mathrm{O}$ direito em manutenção é um poder que repete sem cessar o evento originário do seu próprio mito: ao aduzir que, à diferença da decisão judicial, a polícia opera a suspensão das duas funções do poder jurídico ao baixar decretos em relação aos quais ela mesma se incumbe do cumprimento, Benjamin desloca nossa atenção para o aspecto nodal do direito, a saber, que a possibilidade da sua aplicação está atrelada

\footnotetext{
${ }^{6}$ A relação entre a aplicação do direito e a sua suspensão é, por assim dizer, o mote da análise de Agamben sobre o poder soberano moderno. A tese do estado de exceção permanente se desenrola nesta zona de inaplicabilidade do direito fora da excepcionalidade, quer dizer, num não-espaço onde a aplicação mesma da norma depende da suspensão operada pela exceção. O salto de Agamben concerne em haver compreendido quão extremos são os não-limites da decisão soberana, ou seja, em haver posicionado muito seriamente a permanência radical da exceção no centro das suas análises. Qualquer decisão e, no limite, a existência mesma do Estado (de) Direito, ergue-se sobre a exceção. Sem embargo, o problema do estado de exceção é, além de um problema metafísico e político, um problema atinente à linguagem e à ontologia: "Tudo acontece como se o direito e o logos tivessem necessidade de uma zona anômica (ou alógica) de suspensão para poder fundar sua referência ao mundo da vida. O direito parece não poder existir senão através de uma captura da anomia, assim como a linguagem só pode existir através do aprisionamento do não linguístico. Em ambos os casos, o conflito parece incidir sobre um espaço vazio: anomia, vacuum jurídico de um lado e, de outro, ser puro, vazio de toda determinação e de todo predicado real. Para o direito, esse espaço vazio é o estado de exceção como dimensão constitutiva" (AGAMBEN, 2004, 93).
}

Mestrando no PPG em Filosofia da Universidade Federal de São Paulo. Brasileiro; residente em Campinas-SP. e-mail: led.Iclt@gmail.com 
à sua própria suspensão. Diríamos, portanto, que a diferença entre a polícia e a decisão "oficial" é, na verdade, uma quase diferença, pois a possibilidade de fazer cumprir os fins colocados pela instituição do direito depende do ato consistente em excepcionar estes fins (Cf. BENJAMIN, 1986, p. 166). Aqui, a fim de apreender a intimidade vital entre a decisão soberana, ou seja, a aplicação do direito, e a exceção, faz-se pertinente que recorramos, de passagem, às reflexões de Benjamin acerca do conceito da indecibilidade do soberano barroco, presente na tese Origem do Drama Barroco Alemão (Ursprung des deutschen Trauerspiels). É o que sugere SeligmannSilva:

Neste sentido, Benjamin observa, não sem ironia, que o espírito policialesco, que parece ser tão compatível com a monarquia soberana, onde ela "representa o poder soberano", reunindo suas funções legislativas e executivas, já nas democracias dá provas da "maior degenerescência imaginável do poder [Gewalf]" (SELIGMANN-SILVA, 2005, 27).

O autor nos fornece, em poucos parágrafos, três características fundantes do poder soberano barroco, a saber, a indecibilidade, o estado de exceção e o martírio. É necessário que compreendamos estes conceitos como numa malha trançada. Não foi dito, entretanto, que o conatus jurídico-soberano consiste justamente em realizar fins através do seu meio essencial, a Gewalt, e, deste modo, fatalmente decidir? Como poderia, então, ser a indecisão uma marca do poder na letra de Benjamin? Vejamos o que realmente se conserva nesta marca, para além de uma mera negação da decisão:

\begin{abstract}
A função do tirano é a restauração da ordem, durante o estado de exceção: uma ditadura cuja vocação utópica será sempre a de substituir as incertezas da história pelas leis de ferro da natureza. Mas a técnica estoica também dá forças para uma estabilização interna equivalente: o controle das emoções, num estado de exceção dentro da alma. Também ela procura uma nova criação, oposta à história - a afirmação da castidade feminina -, não menos afastada da primeira e inocente Criação que a constituição ditatorial do tirano. Se a característica desta última é a devoção à coisa pública, a da primeira é o ascetismo físico. Daí a posição de primeiro plano ocupada pelas princesas castas no drama de martírio (BENJAMIN, 1984, 97).
\end{abstract}

A indecisão do soberano barroco nada mais é do que a compulsão (Zwang) incessante do seu poder de decidir. O domínio invectivo do subjectum sobre a história, com seu projeto de "substituir as incertezas da história pelas leis de ferro da natureza", inaugura inevitavelmente o seu próprio mito, o mito do controle e da captura da contingência sob o véu metafísico do nómos. Aqui, a palavra mesma do soberano se 
torna, como afirmou Benjamin, enquanto decisão fixada no espaço e no tempo, história passível de ser reconvertida em espaço de decisão soberana. A exceção permanente condiz, como bem notou Agamben, com este duplo grau de insuficiência do dualismo metafísico entre nómos e phýsis, linguagem e mundo: por um lado, o contingente jamais alcança a dimensão de pureza da lei; por outro, em razão da própria natureza inapreensível do contingente, a lei jamais consegue ser cumprida em totalidade, necessitando esmigalhar-se em particularidades a fim de adequar a história. Neste território de vazio perpétuo, é a mímesis do mito que novamente assume o primeiro plano do movimento soberano, já que a indecisão implica, de fato, na permanente repetição de uma decisão que nunca se aproxima da sua plenitude, contudo que também jamais cessa de testá-la. O que resta ante a Gewalt peculiar ao subjectum soberano é, por conseguinte, um estado efervescente de produção autoperenizável da exceção. A regra da soberania diz respeito, enquanto tomada de decisão indecisa ao infinito, à reprodução permanente da exceção. É exatamente o que teremos, já bastante amadurecido, na Tese VIII de Sobre o Conceito de História: “A tradição dos oprimidos nos ensina que o 'estado de exceção' no qual vivemos é a regra. Precisamos chegar a um conceito de história que dê conta disso" (BENJAMIN apud LÖWY, 2005, 83). Sendo impossível de fato decidir de uma vez por todas, o soberano é compelido ao martírio, ou seja, à compulsão mimética de um mesmo ato.

Perscrutamos a repetição que o direito perfaz em torno da sua própria essência, ou seja, enquanto força mantenedora da retomada mesma do seu instante instituidor pré-histórico - autolegitimador e indeterminado - onde o conatus subjetivo colapsa o tempo, transpondo-se em mito. Foi ademais demonstrado que o teor da ameaça, neste circuito, é ambivalente: o direito atual se mostra ameaçador na forma do destino (Shicksal); aquilo que aparece como ameaça ao direito atual, por sua vez, é ameaçador enquanto o seu outro (Alienos). Vimos a mímesis atrelada ao destino, isto é, ao direito atual que institui e se mantém. Porém, será que o problema radical da crítica do direito (Gewalt) está atenta somente ao mito de um direito atual? Pois não é no direito atual que o mito da Gewalt se encerra. Ela também reside no projeto latente que o outro do subjectum jurídico alimenta, o projeto de instituir um novo direito, quer dizer, de criar o seu próprio ciclo de instituição e manutenção do poder. Deste modo, a mímesis e o mito da Gewalt alcançam inclusive o combate mortal entre o direito e o seu outro, contaminando a história ela mesma com a essência e, portanto, com a 
necessidade da existência da autoridade (subjectum, soberania e Gewalt), como se fosse inevitável que um corpo político sempre assumisse a relação violenta entre meios e fins. No limite, a análise benjaminiana edifica-se, inclusive, como uma crítica extraordinariamente profunda à própria história das revoluções. Seja nos eventos de 1789 ou nos de 1917, foi o espectro da Gewalt que sempre irrompeu no coração dos homens para repetir uma história marcada pela catástrofe ${ }^{7}$, isto é, uma história assinada com sangue e sustentada em carnificina sob a sombra da batalha mimética eterna entre vitoriosos e derrotados.

Como compreender isto que remete, no fundo, ao mito da autoridade alojado no espírito da história do Ocidente? Como compreender que, contra a violência e o domínio do direito atual, o novo direito pretenda dele emancipar-se repetindo exatamente o mesmo modelo de autoridade que o oprime?

\section{Notas sobre messianismo e potência}

Que a marcha gutural de nossa época deslize pela história afinando tudo o que encontra sob a clave ensurdecedora da catástrofe, isto as reflexões precedentes sobre a obra de Benjamin nos indicaram até o pavor ou a exaustão. Entretanto, o que o pessimismo crítico de Benjamin nos ofereceria de suficientemente potente em vistas do desmantelamento radical deste destino? Há fôlego para uma saída ou o autor nos teria abandonado ao relento com este fardo deplorável? Categoricamente, a letra benjaminiana jamais nos deixa sozinhos na prisão mítica da história, pervertida em progresso, para termos a pele carcomida lentamente até atingirmos o zênite da massa moribunda. A letra benjaminiana está encharcada, seja no plano da sua filosofia da história, da crítica ao poder ou da estética, de vida revolucionária, de uma persistência inconveniente da potência. Atirados de súbito em meio à marcha mítico-destinal, como seria possível interromper o seu continuum? Conforme Benjamin, "É possível que as revoluções sejam o ato, pela humanidade que viaja nesse trem, de puxar os freios de

7 O conceito de catástrofe é fundamental para se compreender a filosofia da história de Walter Benjamin, já que representa precisamente esta marcha violenta produtora dos oprimidos: "Rejeitando o culto moderno da Deusa Progresso, Benjamin coloca no centro de sua filosofia da história o conceito de catástrofe. "Em uma das notas preparatórias às Teses de 1940, observa: 'A catástrofe é o progresso, o progresso é a catástrofe. A catástrofe é o contínuo da história'. A assimilação de progresso e catástrofe tem, antes de mais nada, uma significação histórica: do ponto de vista dos vencidos, o passado não é senão uma série interminável de derrotas catastróficas" (LÖWY, 2002, 204). Ora, será justamente este contínuo catastrófico da história, erguida sobre uma história "não contada" dos oprimidos, que a noção benjaminiana de revolução intentará romper.

Mestrando no PPG em Filosofia da Universidade Federal de São Paulo. Brasileiro; residente em Campinas-SP. e-mail: led.Iclt@gmail.com 
emergência" (BENJAMIN apudLÖWY, 2005, 93-94). Apresentaremos, doravante, três temas absolutamente íntimos instalados na obra do autor que nos apontarão, no revés de um projeto instituidor ou estratégico-racional revolucionário, horizontes de liberdade a partir dos quais poderemos pensar a mais autêntica potência humana, aquela que liquida com o olhar todo lastro de repetição mítica: a violência divina, o estudante e o messianismo.

Nos parágrafos derradeiros de Crítica da Violência: Crítica do Poder, Walter Benjamin opõe ao poder mítico do direito, ou seja, a violência que o institui e o mantém, o poder divino. Atinente ao primeiro, vimos que concentra em torno de si o caráter cíclico da mímesis da Gewalt, ora como repetição da violência fundacional enquanto mediadora dos fins instituídos, ora como repetição da própria violência fundacional agora tomada de assalto nos domínios do direito atual, na forma de vingança, pelo seu outro que inaugura novo impulso instituidor e mantenedor do direito. Em suma, buscou-se demonstrar que o mito central que se repete, não obstante quem esteja momentaneamente no topo da gangorra, redunda sempre no mesmo. O poder divino, por seu turno, irrompe como acontecimento interruptor da marcha mítica. Ele é o expediente do imprevisível ante a repetição, destruidor do mito da autoridade:

Se o poder* mítico é instituinte do direito, o poder* divino é destruidor do direito; se aquele estabelece limites, este rebenta todos os limites; se o poder mítico é ao mesmo tempo autor da culpa e da penitência, o poder* divino absolve a culpa; se o primeiro é ameaçador e sangrento, o segundo é golpeador e letal, de maneira não-sangrenta (BENJAMIN, 1986, 173).

Não é uma trivialidade enfatizar que a oposição do poder divino ao poder mítico proposta por Benjamin nada tem a ver com a oposição, de lastro metafísico, entre o subjectum soberano e o seu outro intrínseca à mímesis da autoridade, isto é, com o que chamamos, momentos atrás, amparados por Wilde, de espelhamento repulsivo. O poder divino é significativamente menos hegeliano do que isso. O poder divino rompe com a relação mítica entre meios e fins para dar espaço a uma vivência sem princípio ou finalidade, uma vivência cuja verve resida não mais no poder de decisão sobre a vida e a morte, porém na recomposição do vazio novamente tomado sob o uso da vida:

Enquanto o poder mítico cria o direito, o poder divino destrói o direito, abrindo caminho para a justiça. O poder mítico pune porque seu objetivo é a expiação Mestrando no PPG em Filosofia da Universidade Federal de São Paulo. Brasileiro; residente em 
da culpa ou a absolvição do culpado. O poder de Deus (ou poder puro), de seu lado, é justo porque não pune, pois o seu fim é a vida. Sua letalidade não é punitiva porque ele não é sangrento, afinal o poder divino não pune ao matar, mas mata para redimir, absolver da culpa (BARSALINI, 2013, 112).

Barsalini anota, recordando comentário de Agamben, que o poder divino está associado à enigmática passagem de Benjamin segundo a qual o caminho para a justiça ou, ainda, o atravessar a porta da justiça abre-se somente sob a condição de um direito não mais aplicado, contudo apenas estudado. A passagem em questão pode ser verificada no ensaio sobre Franz Kafka:

\begin{abstract}
Pode verdadeiramente o direito ser posto em movimento, em nome da justiça, contra o mito? Não: como jurista, Bucéfalo permanece fiel às suas origens. Parece, no entanto, - e nisto poderia consistir, no sentido de Kafka, a novidade para ele e para a profissão de advogado - que ele não exercita sua profissão. O direito que não é mais exercido e que é só estudado, é a porta da justiça. A porta da justiça é o estudo (BENJAMIN, 1975, 105).
\end{abstract}

Ora, nos deparamos aqui com uma figura reiterada no pensamento de Walter Benjamin desde os seus escritos de juventude, a saber, o estudante. Que significado especial guarda o estudante aos olhos do autor? As últimas páginas do ensaio sobre Kafka são dedicadas a ele. Lá, o estudante representa fundamentalmente três coisas: a atenção, o esquecimento e a finitude. A atenção do estudante está atrelada a uma incapacidade latente e incontornável em se resignar a qualquer tipo de estado de dormência do espírito, mergulhando, ao contrário, em cada sutil manifestação, para ele sempre excepcional, daquilo com o que se compromete em sua permanente vigília. Os estudantes, bem como os loucos e os ajudantes, são criaturas imunes à interpelação apassivadora dos mecanismos de arrefecimento que os cercam, censuram e compactam; eles são, por assim dizer, na mesma trilha que d'Os Incompreendidos de Truffaut, os incansáveis: : 'Dormir... Sim!', disse o estudante, 'Dormirei quando tiver terminado meus estudos'. É preciso pensar nas crianças que vão dormir de má vontade" (BENJAMIN, 1975, 102). Mas a atenção jamais se deixa sacralizar por uma só atividade; a dormência do espírito é algo que se encontra por toda parte, inclusive - ou talvez principalmente - com a máscara da vigília. Jurado de fidelidade à lei da atividade sacra, devedor de seu cumprimento, vem instalar-se insuportavelmente pesada sobre a vida do estudante a culpa. É em razão disso que, ao lado da atenção incansável, experimenta-se também o esquecimento como porta

\footnotetext{
${ }^{8}$ Cf. BENJAMIN, 1975, p. 101-102.

Mestrando no PPG em Filosofia da Universidade Federal de São Paulo. Brasileiro; residente em Campinas-SP. e-mail: led.Iclt@gmail.com
} 
da justiça, pois "O esquecimento [...] refere-se sempre ao melhor, porque refere-se à possibilidade da redenção" (BENJAMIN, 1975, 102). No mesmo grau de profundidade que o estudante se atira atencioso às questões do mundo, já também redime-se de qualquer comprometimento coercitivo capaz de impor-lhe um dever que, no fundo, ele sabe que nunca poderá cumprir. Portanto, o esquecimento acoplado à atenção é o único expediente a partir do qual se torna possível a recuperação da zona de vazio mortificante instaurado pela autoridade. Num salto, porém, o esquecimento nos redime precisamente desta lei e da sua porta de entrada intransponível. Não havendo mais dever progenitor do pecado, abre-se um espaço onde a destituição da autoridade, ao redimir-nos da culpa, inaugura um campo potente de experiência plena. Aqui não há falta, martírio ou penitência, apenas a reconexão radical da experiência humana, liberta da obediência e do destino, com seu próprio nada. Esmagado pela autoridade, o homem nada faz; redimido, ele pode tudo:

\begin{abstract}
Talvez esses estudos não tenham significado nada. No entanto, estão muito próximos desse nada que apenas torna útil alguma coisa, e que é o Tao. Era isso que Kafka perseguia no seu desejo de "martelar uma mesa com habilidade paciente e minuciosa e ao mesmo tempo não fazer nada; mas não de forma que se possa dizer: 'Para ele, martelar não é nada', e sim 'Para ele, martelar é um verdadeiro martelar e ao mesmo tempo nada' [...]" (BENJAMIN, $1975,102-103)$.
\end{abstract}

Ao romper com o movimento autômato do destino mítico, o fazer verdadeiro, aquele que é, ao mesmo tempo, o seu próprio nada, recompõe-se enquanto finitude permanente donde se experimenta a cada vez o novo plenificante. Em suma, o estudante, circuito simultâneo entre atenção, esquecimento e finitude, se reconcilia com a potência outrora drenada pela autoridade, em cujo lugar restara apenas um deserto inóspito e sagrado, e que agora liquida com todas as portas trancadas, com todo segredo e toda miséria. Nada se sacraliza na vida do estudante. Para ele, nada jamais é o mesmo e, todavia, cada instante já é tudo. Ademais, talvez uma sucinta incursão através das linhas do jovem Benjamin nos auxilie a completar o enigma alojado nesta criatura incansável.

Em A Vida dos Estudantes (1915), um Benjamin ainda engajado na militância estudantil decide experimentar uma narrativa crítica à posição do estudantado alemão da época. São multíplices os temas encontrados neste ensaio que permanecerão no centro das preocupações do autor até o final de sua vida. A noção histórica do progresso, a repetição dos modelos de dominação, a alienação da vida criadora, a 
"experiência", a tarefa revolucionária, o presente, são todos temas que podemos conferir, por exemplo, também nas teses Sobre o Conceito de História, de 1940. No ensaio em questão, entretanto, é o debate em torno da história, em sua relação com a figura do estudante, que ganha primazia. De maneira bastante específica, é o atual estado de desprendimento da história em relação à experiência presente o que mais atormenta o autor nos descaminhos assumidos pelo estudantado alemão, ou, em suas próprias palavras, a incapacidade na qual seus contemporâneos se enredaram de "libertar o vindouro de sua forma desfigurada, reconhecendo-o no presente" (BENJAMIN, 2009, 32). A história teria adquirido movimento independente de todos os homens, obliterando a possibilidade de qualquer transformação da sua direção. Por um lado, a ideia do progresso se torna a grande responsável por este desencontro letal, representativa de um otimismo parco à espera das realizações humanas, bem como a submissão à autoridade da "experiência", que "é o medo do vindouro e, ao mesmo tempo, um pactuar sereno com esse filisteísmo inevitável, que surge agradavelmente perante nossos olhos como "velho senhor'” (BENJAMIN, 2009, 4445). ${ }^{9}$ No centro deste problema está ainda a perversão da vida do estudante em mero preparo, adestramento ou enformação em torno do saber profissionalizado, que indica, dentre outras coisas, o espraiamento da existência em diversas zonas sacras de particularização da experiência. Pontualmente, o que o autor observa neste trânsito cativo é a transformação do homem em função alienada:

\begin{abstract}
A falsificação do espírito criador em espírito profissional, que vemos em ação por toda parte, apossou-se por inteiro da universidade e a isolou da vida intelectual criativa e não enquadrada no funcionalismo público. O desprezo, típico de casta, por grupos de artistas e eruditos livres, estranhos ou frequentemente até hostis ao Estado, é um sintoma claro e doloroso dessa situação (BENJAMIN, 2009, 39).
\end{abstract}

Mas quem é então o estudante autêntico para Benjamin, se assim podemos chamá-lo? A menção precedente não foi logo exposta sem nenhum propósito: "libertar o vindouro de sua forma desfigurada, reconhecendo-o no presente" é, como alude o

\footnotetext{
${ }^{9}$ A "experiência" à qual aqui remetemos é aquela de cunho supressor que Benjamin se propõe analisar em seu ensaio homônimo de 1913. Em "Experiência", Benjamin parece captar de maneira bastante incisiva a repetição (mímesis) da forma mítica encarnada no "adulto" - chamado em $A$ Vida dos Estudantes, no âmbito estudantil mas com o mesmo sentido, de "velho senhor" -, que suprime a potência da juventude ao inseri-la no ciclo de uma história inevitável. "Mas por que então a vida é absurda e descontrolada para o filisteu? Porque ele só conhece a experiência, nada além dela; porque ele próprio se encontra privado de consolo e espírito. E também porque ele só é capaz de manter relação íntima com o vulgar, com aquilo que é o 'eternamente-ontem'” (BENJAMIN, 2009, 22).

Mestrando no PPG em Filosofia da Universidade Federal de São Paulo. Brasileiro; residente em
} 
autor, o cerne da experiência crítica do estudante. O estudante é, precisamente, aquele que reabilita o devir no âmbito de sua mais potente imanência, aquele que é instado pela existência a revigorar, a cada instante, a diferença que lhe corre nas veias e corrói todo tipo de normatização e normalização, atoladouros míticos do "eternamente-ontem". Porque o "marcante na vida dos estudantes é, de fato, a aversão em submeter-se a um princípio, em se deixar imbuir de uma ideia" (BENJAMIN, 2009, p. 32), o estudante escapa a qualquer invectiva dos procedimentos de automatização do corpo e espírito, implacável que é sua potência e que o torna escorregadio ante a tentativa de aprisionamento pelas instâncias de controle. Essa criatura incansável faz da sua própria existência no mundo um espaço radical de abertura e acesso a todos os seus poros, meandros e possibilidades. Talvez fosse isso o que Benjamin pretendia quando falou da universidade enquanto comunidade de homens criadores, e esta alçada à universalidade de toda experiência:

\begin{abstract}
A comunidade dos homens criadores eleva todo estudo à universalidade: sob a forma da filosofia. Não se conquista tal universalidade à medida que se expõem questões literárias ao jurista, questões jurídicas ao médico [...], mas sim na medida em que a comunidade cuida e consegue por si mesma que, ante toda particularização do estudo especializado [...], acima de todo funcionamento das escolas especializadas, ela própria, a comunidade universitária enquanto tal, seja a criadora e mantenedora de sua forma filosófica, e isso não com os questionamentos da filosofia especializada e limitada, mas sim com as questões metafísicas de Platão e Espinosa, dos românticos e de Nietzsche (BENJAMIN, 2009, 41).
\end{abstract}

Não podemos prescindir de uma boa dose de cautela a fim de evitar leitura apressadamente traidora desse excerto. O jogo se dá entre os conceitos de universalidade e particularização. Eles têm sentido muito peculiar no contexto em que os analisamos. A universalidade nada tem a ver com a pretensão de despir o mundo por completo de todos os seus mistérios e encantos ao recobri-lo com o véu total da verdade; aqui, ao contrário, universalidade quer dizer "aberto a todos", livre de segredos e acessível ao uso. Particularização, por sua vez, remete à sacralidade das formas, isto é, à maneira como se organiza a existência através da sua mutilação em infinitas mônadas esparsas, seja na forma do indivíduo egóico, da profissão, da ciência e dos saberes, da linguagem, das técnicas, da economia, da função social etc. Já a universalidade de Benjamin, esta é altamente profana. Ela profana, enquanto vida autêntica do estudante, toda particularização da existência, isto é, tudo aquilo que pretenda se afastar do homem para, tão logo, se atirar contra ele. Ela reconecta a 
existência, eliminando suas zonas vazias e intocáveis de não-experiência. ${ }^{10} \mathrm{O}$ estudo do estudante, que, cada vez mais, nos conduz para uma perspectiva não apenas profana mas, sobretudo, anárquica da experiência histórica, reverbera a práxis permanente da abertura ${ }^{11}$, uma experiência plenificante em cujo seio apenas poderemos vigorar, no limite, se também experimentarmos a recomposição da linguagem. ${ }^{12}$ Aqui, inclusive a filosofia deve superar seu caráter especializado, como doxografia ou saudosismo metodológico, e retomar as questões radicais dos grandes pensadores, aqueles que falaram das coisas às quais todos já sempre têm acesso e das quais todos participam.

O devir imanente do estudante, esta potência destituidora de todo princípio, aparece novamente no encerramento do ensaio, incrustado de fortíssima tendência anárquica: "Todo aquele que questionar a sua vida com a exigência mais elevada encontrará os próprios mandamentos. Libertará o vindouro de sua forma desfigurada, reconhecendo-o no presente" (BENJAMIN, 2009, 47). A destituição do aparato mítico, que recolhe em si as diversas máscaras da autoridade, reside no lapso de potenciação da existência anunciado por Benjamin, alguns anos mais tarde, também no encerramento de seu Crítica da Violência: Crítica do Poder. Ali, é o poder divino que

\footnotetext{
${ }^{10}$ Sem dúvida, Agamben se debruçara demoradamente sobre essas questões. A reconciliação com a existência histórica no mundo, a restituição ao uso e a profanação dos dispositivos sacros, bem como o devir desta comunidade de homens criadores, é propriamente o mote do ensaio Elogio da Profanação (Elogio della Profanazione). Lá, o pensador explora os horizontes de uma teoria da destituição permanente das formas enrijecidas e sagradas, onde o que tem lugar não é mais o ciclo de reconfiguração do sacro, mas uma teoria do uso como aquela do martelar e do nada recordada por Benjamin a partir de Kafka: "O uso a que o sagrado é devolvido é um uso especial, que não coincide com o consumo utilitarista. [...] As crianças, que brincam com qualquer bugiganga que thes caia nas mãos, transformam em brinquedo também o que pertence à esfera da economia, da guerra, do direito e das outras atividades que estamos acostumados a considerar sérias" (AGAMBEN, 2007, p. 67). E finaliza explicitando o prospecto daquela comunidade mergulhada no devir imanente, a comunidade de estudantes, de criadores: "A profanação do improfanável é a tarefa da geração que vem" (AGAMBEN, 2007, 79, grifo nosso).

${ }_{11}$ Neste sentido, nos aproximamos dos comentários de Michael Löwy acerca da Tese XVIla de Sobre o Conceito de História: "Trata-se de opor uma concepção aberta da história como práxis humana - rica em possibilidades inesperadas, que podem produzir o novo - a toda doutrina teleológica, confiante nas 'leis da história' ou na acumulação gradual de reformas na via certa e garantida do Progresso infinito" (LÖWY, 2005, 136).

12 É o que sugere Benjamin acerca da possibilidade de uma comunidade desinvestida dos meios violentos, sejam eles legítimos ou ilegítimos, e que o mesmo nomeia de meios puros ou não-violentos: "Seu exemplo mais profundo talvez seja a conversa, considerada como uma técnica de mútuo entendimento civil. Ali, um acordo não-violento não apenas é possível, mas a eliminação por princípio da violência* pode ser explicitamente comprovada com um tipo de relação importante: a impunidade da mentira. [...] Quer dizer que existe uma esfera de entendimento humano, não-violenta a tal ponto que seja totalmente inacessível à violência: a esfera propriamente dita do "entendimento", a linguagem" (BENJAMIN, 1986, 168, grifo nosso).
}

Mestrando no PPG em Filosofia da Universidade Federal de São Paulo. Brasileiro; residente em Campinas-SP. e-mail: led.Iclt@gmail.com 
assume, "golpeador e letal", a tarefa da destituição radical da autoridade que é o direito:

Deve ser rejeitado, porém, todo poder* mítico, o poder* instituinte do direito, que pode ser chamado de um poder que o homem põe (schaltende Gewalt). Igualmente vil é também o poder* mantenedor do direito, o poder* administrado (verwaltete Gewalt) que Ihe serve. O poder divino, que é insígnia e chancela, jamais um meio de execução sagrada, pode ser chamado de um poder de que Deus dispõe (waltende Gewalt) (BENJAMIN, 1986, p. 175).

O poder divino é um poder que dis-põe toda autoridade. Ele é o salto para trás que destitui aquilo antes fincado na terra como prisão destinal da humanidade. Assim, "A nova era histórica é anunciada, como aquela sem um poder do Estado. O poder puro, revolucionário e humano que Benjamin evoca, é posto em paralelo com o poder divino [...]" (SELIGMANN-SILVA, 2005, 30). Na malha conceitual benjaminiana, este poder revolucionário, meio puro que rompe com o ciclo de instauração mítica ao desinstaurar toda autoridade, princípio e dever, se transformará naquilo que os assim chamados escritos maduros darão o nome de messianismo revolucionário. Compreender o que de elementar está implicado nesse conceito é a tarefa que, já chegando ao fim do presente trabalho, ficará como o fôlego revigorante que buscávamos no início deste tópico.

O messianismo de Walter Benjamin representa o instante decisivo no qual a marcha mítica da história finalmente será interrompida; representa, sobretudo, aquele devir radical que nos liberta da armadilha do progresso e das leis da "experiência", marcando o irromper de uma nova era histórica a partir da qual o ciclo da barbárie por fim cairá por terra. "Finalmente" e "por fim", entretanto, são termos contaminados por uma concepção de messianismo que novamente nos envisca na alienação do homem em relação à história, um messianismo que se alimenta da promessa de "chegada" de uma sublevação externa que, a qualquer momento, poderia acontecer, mas que estaria reservada ao destino de sua própria realização. Aos homens, bastaria simplesmente aguardar pelo momento certo. Ora, nada mais contrário à noção benjaminiana de messianismo. Nesta, nenhuma força transcendente virá em missão de salvação para livrar os homens da catástrofe. A interrupção messiânica do progresso está inexoravelmente atrelada à possibilidade decisiva de que os homens mesmos recomponham os laços perdidos com a história, isto é, que injetem novamente o devir na "ordem do dia", na imanência que só o presente pode realizar. 
Em outros termos, o messianismo revolucionário de Benjamin é, inclusive e primordialmente, a redenção baseada no movimento de retorno em direção à antípoda do colapso da temporalidade: ou seja, o tempo ele mesmo. Romper com a afinação da catástrofe significa romper, portanto, com o destino. Tendo em vista, por conseguinte, que o problema da revolução é também o problema da história e do tempo, o sentido que intentamos elucidar acerca do messianismo goza, de maneira bastante específica, de duas fontes, a saber, as Teses XIV e XVIla de Sobre o Conceito de História.

A recomposição revolucionária da temporalidade é anunciada logo no início da Tese XIV: "A história é objeto de uma construção, cujo lugar não é formado pelo tempo homogêneo e vazio, mas por aquele saturado pelo tempo-de-agora (Jetztzeit)" (BENJAMIN apud LÖWY, 2005, 119). O tempo-de-agora significa propriamente para Benjamin o tempo histórico no qual a humanidade recupera seus laços perdidos com a tradição e interrompe a continuidade mítica do progresso. Ao puxar os "freios de emergência" da história, os homens de fato param o seu desenrolar violento; note-se que, desta maneira, a perspectiva revolucionária de Benjamin não se aloja de modo algum numa teoria tradicional da ação, tal como o faziam as correntes marxistas predominantes na época, porém, na contramão deste processo, o autor pensa o salto revolucionário precisamente enquanto não-ação, o stop total do desenvolvimento do progresso. ${ }^{13}$ Aqui, a Tese VII novamente se nos mostra preciosa: se a edificação monumental da cultura recolhe sob seus mais belos ornamentos a barbárie produzida incessantemente pela marcha dos vencedores, acumulando pela eternidade carne e espíritos apodrecidos em sua base, então a tarefa revolucionária consiste, no revés, em romper com a repetição (mímesis) deste tempo mortificante. Em outros termos, a revolução deve depor o mito - ou seja, o poder divino, aquele que dis-põe (waltende Gewalt) -, e não dar novo impulso ao seu continuum - o poder mítico, aquele que põe (schaltende Gewalt) -, e isto porque "o materialista histórico, na medida do possível, se afasta dessa transmissão. Ele considera como sua tarefa escovar a história a contrapelo" (BENJAMIN apud LÖWY, 2005, 70).

\footnotetext{
${ }^{13}$ Para uma discussão profundamente acurada sobre o problema da ação e a via profano-revolucionária da não-ação, conferir a leitura que Barsalini elabora no tópico Georges Sorel, Walter Benjamin, Giorgio Agamben e o problema da revolução permanente, de sua tese. Cf. BARSALINI, 2013, p. 186 ss.

Mestrando no PPG em Filosofia da Universidade Federal de São Paulo. Brasileiro; residente em
} 
No limite, o tempo-de-agora revolucionário está às voltas com a veia teológica do pensamento de Benjamin. Ele tem correspondência com o kairos, o tempo plenificante da história da humanidade, lá onde ela verdadeiramente se realiza, em oposição ao chronos, um tempo sempre fora do nosso alcance e que nos engole a cada instante (Cf. LÖWY, 2005, 119). Neste último, tanto a catástrofe "final" quanto a "chegada" da salvação ficam relegados a uma zona transcendente em relação a qual os homens não têm nenhuma influência; é, pois, o espaço de vazio que dá continuidade ao mito, a falta permanente a que é negada a experiência do homem e que o dista infinitamente da perdição ou da salvação finais. Kairos, por seu turno, liquida qualquer vazio, distância e falta. Ele reúne, no agora, a história dos oprimidos, dos que tombaram ante a muralha e jazem sob seu peso imenso, e o devir messiânicorevolucionário, desfigurado pela história alienada:

\begin{abstract}
Nesse horizonte de pensamento, a origem não está situada num passado cronológico: ela é sempre contemporânea do devir histórico - e não cessa de funcionar nesse vir-a-ser, do mesmo modo como o embrião continua atuando nos tecidos do organismo maduro; assim também ocorre na vida do bebê, que continua atuando na vida psíquica do adulto. [...] O tempo que resta, o tempo atual é o tempo do agora (Jetztheit), o tempo messiânico da revolução (GIACOIA JR., 2015, 16).
\end{abstract}

O tempo do agora, o tempo revitalizado a partir da libertação imanente do devir e da reparação do passado, é ele mesmo o tempo da revolução. Aqui, a Tese XVIla nos vem em auxílio: "Marx secularizou a representação do tempo messiânico na representação da sociedade sem classes. [...] Na realidade, não há um só instante que não carregue a sua chance revolucionária" (BENJAMIN apud LÖWY, 2005, 134). O tempo do agora, o único tempo da existência, é aquele que nos resta como instante messiânico da revolução. Reconciliado com sua própria história e destruído o destino mítico do progresso, o homem enfim reconhece a quem cabe a missão de interromper a marcha fúnebre, quem é, de fato, o Messias: "Não há um Messias enviado do céu: somos nós o Messias, cada geração possui uma parcela do poder messiânico e deve se esforçar para exercê-la" (LÖWY, 2005, 51, grifo nosso). Se o tempo é o presente, o presente cabe apenas aos homens.

Com efeito, a perspectiva revolucionária de Benjamin, como aludiu com muita astúcia Giacoia Jr., nos atira para trás em direção aos tópicos contidos nos ensaios de 1928 dedicados à criança, intitulados Velhos Brinquedos e Brinquedos e Jogos. A importância da criança para a noção de Benjamin acerca da revolução se apresenta, 
no primeiro ensaio, com a tematização da potência revolucionária incrustrada no desejo de brincar. Postada no centro de um mundo sufocado pelas determinações e categorias enformadoras das funções sociais preconcebidas, as quais interpelam a existência de indivíduos, objetos, ideias e, porquê não, brinquedos, a criança mergulha, na experiência mesma do brincar, em um novo e despretensioso mundo, potenciado pela fruição imanente das pequenas criações da brincadeira e onde ela se liberta para uma experiência que é inextricavelmente íntima de seu ser. O brincar da criança é inocentemente implacável com a prévia destinação que embutiram nas coisas. À lógica do "manual de instruções", mecanismo ideológico que traduz o automatismo da vida burguesa adulta, a criança oferece a recuperação do brinquedo através do seu próprio uso potente, ou, doutra maneira, precisamente extraviando aquilo a que foi imposto um destino. Assim, "Uma vez extraviada, quebrada e consertada, mesmo a boneca mais principesca transforma-se numa eficiente camarada proletária na comuna lúdica da criança" (BENJAMIN, 2009, 87). Em Brinquedos e Jogos, por fim, é o paradoxo da permanência do novo que está posto em questão. A criança, para Benjamin, experimenta um gênero muito peculiar de repetição no âmbito de seu brincar. A grande regra do jogo infantil seria a regra do "mais uma vez!", "de novo!". Sem embargo, a repetição da criança nada tem a ver com a repetição mimética, pois aquilo que se repete para a ela consiste radicalmente num novo início da brincadeira, isto é, na repetição daquilo que é impossível repetir-se. 0 espírito da novidade, da transformação radical, da ruptura com aquilo que jamais tem seu termo, da "revolução", é para a criança a única continuidade: "Para ela, porém, não bastam duas vezes, mas sim sempre de novo, centenas e milhares de vezes. [...] A criança volta a criar para si todo o fato vivido, começa mais uma vez do início" (BENJAMIN, 2009, 101).

Visto que, para Benjamin, a revolução persiste no agora e o encharca de um devir indelével, devir que repara inclusive os estigmas do passado, visto que não é sobre um novo - mas velhaco - processo de instauração de outra autoridade que o autor deposita a possibilidade revolucionária, mas, sim, sobre a não-ação, o stop, referente a uma espécie de ethos destituinte de toda autoridade, culpa e alienação, caminhamos inelutavelmente para a tese de que a "teoria" benjaminiana da revolução concerne, de fato, à revolução permanente. É a maneira, e a acompanhamos, como interpreta Barsalini:

Mestrando no PPG em Filosofia da Universidade Federal de São Paulo. Brasileiro; residente em Campinas-SP.e-mail: led.Iclt@gmail.com 
[...] os trabalhos de Sorel e de Benjamin, até os limites por nós conhecidos, e de Agamben, até o momento presente, não dão qualquer espaço para 0 finalismo, tratando-se de obras que concebem a transformação humana na sua própria abertura, sendo ela uma transformação "em aberto", que nunca se encerra. Sorel, Benjamin e Agamben são, portanto, autores que pensam a transformação da humanidade na perspectiva da revolução permanente (BARSALINI, 2013, 185).

Ademais, também Michael Löwy assenta a sua análise acerca da concepção histórica, revolucionária e humana na obra de Benjamin sobre o horizonte da abertura enquanto seu expediente crítico máximo. Na seção conclusiva de seus comentários às teses Sobre o Conceito de História, Löwy aduz que as reflexões do pensador alemão apontam para um conceito de história aberta, ao qual o primeiro designa como um marxismo da imprevisibilidade (Cf. LÖWY, 2005, 149). A história seria, para Benjamin, a manifestação mais autêntica da potência. Absolutamente nada, sequer o passado, jamais se encontra com seu fechamento definitivo. A possibilidade radical constitui, por assim dizer, a "lei" anárquica da existência histórica. Destarte, "A história aberta quer dizer, então, do ponto de vista político, considerar a possibilidade - não a inevitabilidade - das catástrofes por um lado, e de grandes movimentos emancipadores, por outro" (LÖWY, 2005 151-152). Extraordinariamente perspicaz, ainda, a atenção de Löwy concernente ao elemento da aposta intrínseca à abertura radical da história (Cf. LÖWY, 2005, 156). Imprevisível e potente, a existência histórica ela mesma é marcada até a medula pela experiência do risco.

O messianismo e a potência inseridos no pensamento de Walter Benjamin pronunciam-se como uma revolução sem vencedores. O Estado e a sua sinonímia, o direito, bem como toda forma de autoridade, estão agora debaixo dos olhos atentos e redentores do estudante. $O$ destino, que um dia nos condenou à culpa eterna, transformou-se em brinquedo de criança. A vingança se dissipou e a mímesis foi fatalmente interrompida pelo Messias, por cada Messias, em cada sutil instante de sua vida. No mais, a revolução benjaminiana está bem longe dos projetos "concretos" de transformação das relações materiais, podendo até soar ingênua e romântica para os grandes "homens sérios e comprometidos" com a causa. Pensamos já haver demonstrado o quão "revisionistas" são, na verdade, esses grandes homens. A noção benjaminiana de revolução nos leva pelas mãos por uma via imensuravelmente mais intensa de transformação. Nos leva para as prisões mofadas de Dostoiévski, para a 
Torá e os teólogos, para o romantismo. Nos leva, especialmente, para a anarché das crianças, insuportável recôndito de extravio do destino.

\section{CONCLUSÃO}

As reflexões de Walter Benjamin acerca do Estado (de) Direito nos encaminharam até uma zona significativamente mais obscura da existência da autoridade moderna. Em Crítica da Violência: Crítica do Poder, vimos que persiste na constituição da essência do direito, isto é, de seu conatus, um elemento de absoluta inclinação consistente em inflar, sempre mais, o seu excedente de domínio, ou seja, que o monopólio da Gewalt, através do qual o direito pode ser conceitual e politicamente delimitado, instaura-se sobre uma espécie de escatologia do subjectum, o centro de gravidade totalizante que a tudo suga para o interior do seu infinito de nada, mostrando-nos que a mímesis do direito, ou ainda, que a mímesis arraigada ao mito da autoridade penetra em níveis muito mais abissais do que as estruturas institucionais do Estado. Ela penetra propriamente nas relações humanas. Ela é injetada constantemente na família, na escola, nos partidos, na ciência, na relação mesma do homem com a existência. A autoridade não está mais circunscrita em torno de uma dádiva celeste, de uma personalidade, de um cargo ou de uma estrutura racional; arrebatou corpo e espírito dos homens, possuiu sua carne. Transformou-se de tal modo no princípio sacro de um culto onde todos são virtualmente vencedores e derrotados. Sua divindade adorada é Urizen, o destino - profetizado por Blake - da Europa (Cf. Figura 1), do Ocidente, do mundo sob o jugo da história desses vencedores. Com efeito, o reino de Urizen só poderia organizar-se nos quadros de uma oikonomia urizeniana. O brilho solar e a medida do deus deslizaram por todas as cavidades da existência, em diferentes intensidades e regiões, sempre porém acometidas pelo mesmo ser.

Mesmo aqueles que se deflagraram contra o opressor - que vestiu tantas máscaras ao longo dos séculos - foram rapidamente seduzidos, no mesmo compasso, pelas graças do deus. O rito de passagem à emancipação foi legitimada, no mais das vezes, com as festividades de outra dominação, com a fundação de outro direito, de outra autoridade. O mito de Urizen enrijece suas fibras na mesma proporção em que novos e mais sujeitos pululam abrasivos sobre a crosta de pele e sangue seco 
que vai se acumulando embaixo dos seus pés. Benjamin contemplou esse cenário medonho no Angelus Novus, de Paul Klee (Cf. Figura 2):

Existe um quadro de Klee intitulado "Angelus Novus". Nele está representado um anjo, que parece estar a ponto de afastar-se de algo em que crava o seu olhar. Seus olhos estão arregalados, sua boca está aberta e suas asas estão estiradas. $\mathrm{O}$ anjo da história tem de parecer assim. Ele tem seu rosto voltado para o passado. Onde uma cadeia de eventos aparece diante de nós, ele enxerga uma única catástrofe, que sem cessar amontoa escombros e os arremessa a seus pés. Ele bem que gostaria de demorar-se, de despertar os mortos e juntar os destroços. Mas do paraíso sopra uma tempestade que se emaranhou em suas asas e é tão forte que o anjo não pode mais fechá-las. Essa tempestade o impele irresistivelmente para o futuro, para o qual dá as costas, enquanto o amontoado de escombros diante dele cresce até o céu (BENJAMIN apud LÖWY, 2005, p. 87).

Talvez Benjamin apenas não tenha notado a origem oculta donde sopra a tempestade violenta. Talvez não haja notado o Blake que aponta para o céu nos mostrando, escondida na penumbra, a figura horrenda que rege a tempestade. Os ventos que arrastam o anjo da história pelas asas são os mesmos que contornam Urizen e desfraldam seu cabelo para o lado, sem contudo mover uma filigrana de seu corpo. O inamovível que a tudo movimenta: eis o cerne da Metafísica, nutrida de Platão e Aristóteles a Hegel e além. Como profanar a divindade, como potenciar a Identidade, como romper o continuum do mito, constituem, no limite, uma pergunta só. Pergunta radical cujo horizonte de respostas estará guardado somente para aqueles que saltarem nus na abertura de uma experiência indizivelmente mais radical da sua própria existência. Pois "Ser radical é apreender algo em suas raízes. Para o homem, porém, a raiz é o próprio homem..." (MARX, 1962, p. 199).

\section{REFERÊNCIAS}

AGAMBEN, Giorgio. Estado de Exceção. Tradução de Iraci Poleti. $2^{\underline{a}}$ Edição. São Paulo : Boitempo, 2004.

Profanações. Tradução e apresentação de Selvino José Assmann. São Paulo : Boitempo, 2007.

BARSALINI, Glauco. Direito e Política na obra de Giorgio Agamben - soberania e estado de exceção permanente. Porto Alegre : Sergio Antonio Fabris Ed., 2013.

BENJAMIN, Walter. "Crítica da Violência : Crítica do Poder". In.: Documentos de Cultura, Documentos de Barbárie. São Paulo : Cultrix : Editora da Universidade de São Paulo, 1986. 
. "Franz Kafka: no décimo aniversário de sua morte". In.: A Modernidade e os Modernos. Rio de Janeiro : Edições Tempo Brasileiro, 1975.

Origem do Drama Barroco Alemão. Tradução, apresentação e notas de Sérgio Paulo Rouanet. São Paulo : Brasiliense, 1984.

Reflexões sobre a Criança, o Brinquedo e a Educação. 2ª Edição. São Paulo : Editora 34, 2009.

ESPINOSA. Ética. Tradução Grupo de Estudos Espinosanos; coordenação Marilena Chauí. São Paulo : Editora da Universidade de São Paulo, 2015.

GIACOIA JR., Oswaldo. Messianismo e Política em Giorgio Agamben. In.: Reflexão. PUC - Campinas. v. 40, n. 1 (2015). Disponível em: http://periodicos.puccampinas.edu.br/seer/index.php/reflexao/article/view/3229/2140.

Acesso: 12/10/2016.

HORKHEIMER, Max. Estado Autoritario. Traducción y presentación de Bolívar Echeverría. Ed. Revista Palos de la Crítica, México, 1980. Disponível em: <http://www.bolivare.unam.mx/traducciones/Horkheimer,\%20El\%20Estado\%20autori tario.pdf>. Acesso: 20/02/2017.

LÖWY, Michael. A filosofia da história de Walter Benjamin. In.: Revista Estudos Avançados. Universidade de São Paulo. v. 16, n. 45 (2002). Disponível em: http://www.revistas.usp.br/eav/issue/view/734. Acesso: 10/08/2016.

. Walter Benjamin: aviso de incêndio - Uma leitura das teses "Sobre o conceito de história”. Organização e comentários de Michael Löwy. São Paulo : Boitempo, 2005.

MARX, Karl. "Manuscritos Econômicos e Filosóficos". In.: FROMM, Erich. Conceito Marxista do Homem. Tradução de Octavio Alves Velho. Rio de Janeiro : Zahar Editores, 1962.

SCHMITT, Carl. Teología Política. Trad. Francisco Javier Conde e Jorge Navarro Pérez. Madrid : Editorial Trotta, 2009.

SELIGMANN-SILVA, Márcio. Walter Benjamin: o estado de exceção entre o político e o estético. In.: Revista Outra Travessia, UFSC. n. 5 (2005). Disponível em: https://periodicos.ufsc.br/index.php/Outra/issue/view/1201/showToc.

Acesso: 13/10/2016. 
Imagens (página seguinte):

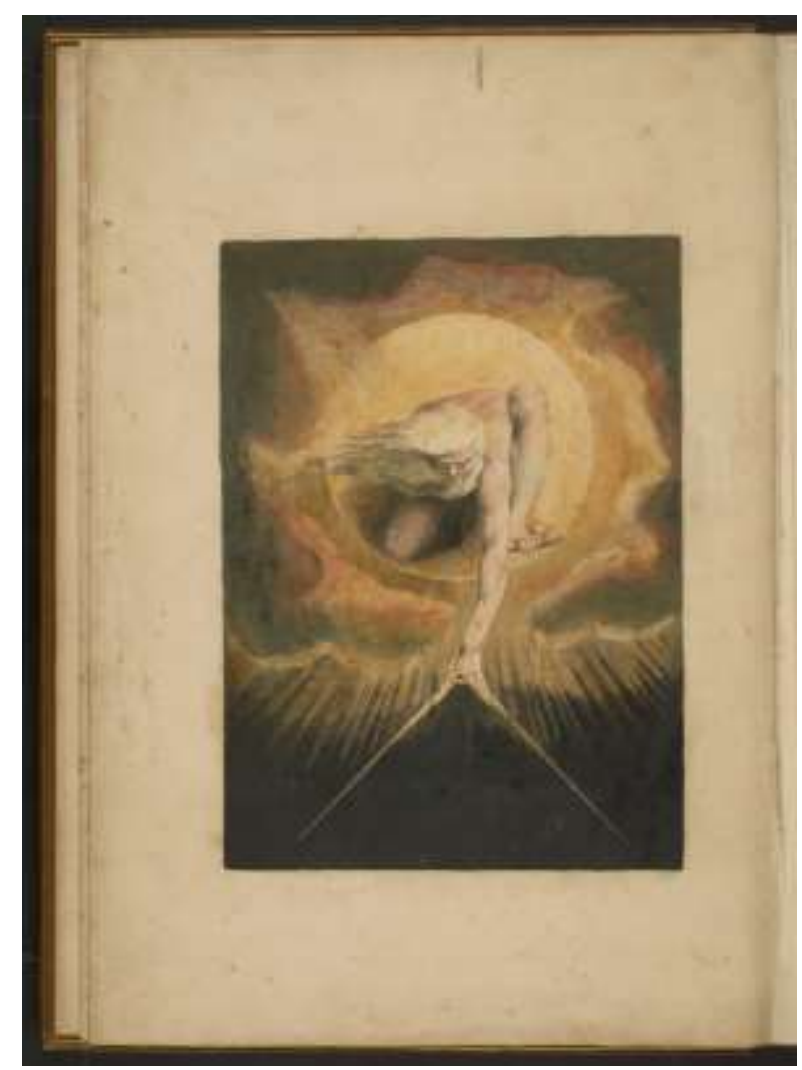

Figura 1. William Blake. Urizen, em Europe, a prophecy [Europa, uma profecia]. Coleção Lessing J. Rosenwald da Biblioteca do Congresso. Londres, 1794. Fonte: endereço virtual da Biblioteca Digital Mundial. 


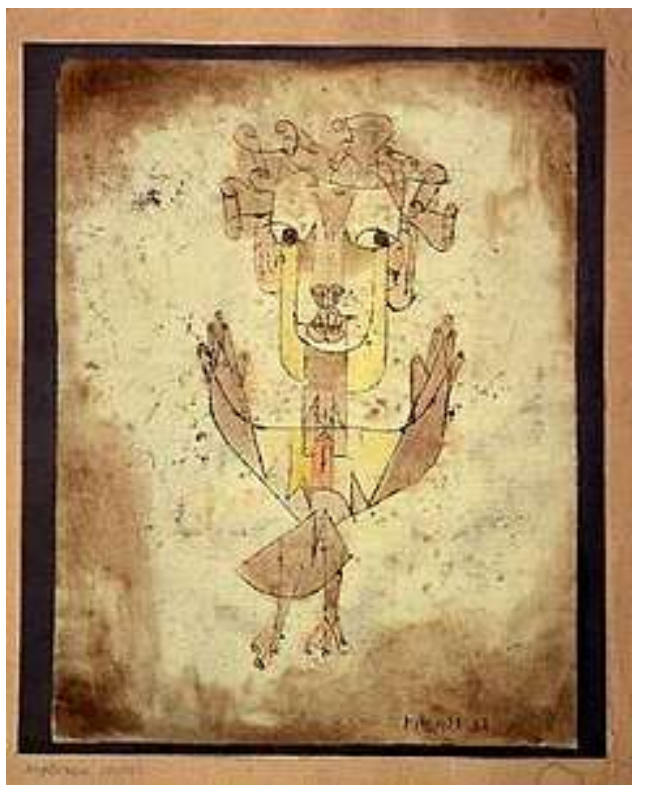

Figura 2. Paul Klee. Angelus Novus. The Israel Museum, Jerusalem. 1920. Fonte: endereço virtual de The Israel Musem, Jerusalém. 